ISSN: 0215-7950

\title{
Penggunaan Bakteri Kitinolitik sebagai Agens Biokontrol Penyakit Busuk Batang oleh Rhizoctonia solani pada Tanaman Kedelai
}

\author{
Utilization of Chitinolitic Bacteria as Biocontrol Agent of \\ Stem Rot Disease by Rhizoctonia solani \\ on Soybean
}

\author{
Andi Khaeruni*, Abdul Rahman \\ Universitas Haluoleo, Kendari 93232
}

\begin{abstract}
ABSTRAK
Penggunaan bakteri kitinolitik sebagai agens biokontrol penyakit busuk batang yang disebabkan oleh Rhizoctonia solani merupakan salah satu alternatif metode pengendalian patogen yang ramah lingkungan. Penelitian ini bertujuan menyeleksi bakteri kitinolitik yang potensial menekan penyakit busuk batang dan memacu pertumbuhan tanaman kedelai. Sebanyak 10 isolat bakteri kitinolitik diuji daya hambatnya terhadap $R$. solani secara in vitro, lima di antaranya-ST21e, SS12b, ST17c, ST27d, dan ST26c-memperlihatkan daya hambat di atas 30\%. Hasil pengujian in planta di rumah kasa, pada pengamatan enam minggu setelah tanam, menunjukkan isolat ST27d dan ST17c yang diinokulasikan pada tanaman kedelai secara nyata mampu menghambat perkembangan penyakit busuk batang dan meningkatkan pertambahan tinggi tanaman dan jumlah daun kedelai. Kedua isolat bakteri kitinolitik tersebut dapat dikembangkan sebagai agens biokontrol penyakit busuk batang yang disebabkan oleh $R$. solani pada kedelai.
\end{abstract}

Kata kunci: bakteri kitinolitik, biokontrol, Rhizoctonia solani

\begin{abstract}
Biological control of stem rot disease caused by Rhizoctonia solani on soybean using chitinolitic bacteria is one of the environmentally friendly control methods of pathogen. The study was conducted to select chitinolitic bacteria and to test their ability to suppress stem rot disease and promote plant growth of soybean. A total of ten chitinolitic bacteria were tested in vitro, and five of isolates i.e: ST21e, SS12b, ST17c, ST27d, and ST26c found to have more than $30 \%$ suppression toward $R$. solani. In planta test under green house condition at six weeks after planting showed that soybean plants inoculated with ST27d and ST17c isolates had significantly lower disease incidence and had increased plant height and leaf number. Both of chitinolitic bacteria isolates are promising as biocontrol agents of stem rot disease caused by $R$. solani of soybean.
\end{abstract}

Key words: biological control, chitinolitic bacteria, Rhizoctonia solani

*Alamat penulis korespondensi: Jurusan Agroteknologi, Fakultas Pertanian, Universitas Haluoleo, Kampus Bumi Tridharma, Jalan HEA Mokodompit, Kendari 93123

Tel: 0401-3193596, Faks: 0401-3193596, Surel: akhaeruni@yahoo.com 


\section{PENDAHULUAN}

Penyakit busuk batang yang disebabkan oleh Rhizoctonia solani merupakan salah satu penyakit cendawan tular yang banyak menimbulkan kerugian pada tanaman budi daya, salah satunya pada tanaman kedelai. Di Indonesia, penyakit ini dapat mengakibatkan kehilangan hasil hingga 100\% jika serangan terjadi pada fase awal pertumbuhan kedelai. Penggunaan fungisida secara berlebihan dan tidak sesuai anjuran untuk pengendalian penyakit ini berdampak negatif terhadap lingkungan. Di sisi lain, pengendalian dengan menggunakan varietas tahan masih kurang karena terbatasnya sumber genetika inang yang tahan terhadap $R$. solani.

Penggunaan bakteri antagonis merupakan salah satu komponen pengendalian yang mulai banyak mendapat perhatian karena memiliki beberapa keuntungan, antara lain (i) tidak mengandung bahan beracun yang bisa menimbulkan residu pada rantai makanan dan pencemaran lingkungan, (ii) tidak memerlukan aplikasi berulang karena bakteri dapat memperbanyak diri selama lingkungan mendukung perkembangannya, (iii) tidak menimbulkan efek samping terhadap organisme yang bermanfaat pada tanaman, dan (iv) dapat meningkatkan ketahanan tanaman terhadap serangan patogen (Wei et al. 1991).

Akhir-akhir ini bakteri penghasil enzim kitinase kembali menjadi perhatian dalam bidang pertanian karena kemampuannya sebagai agens biokontrol patogen tanaman, khususnya cendawan patogen yang memiliki kitin pada dinding selnya (Suryanto et al. 2010). Beberapa bakteri kitinolitik yang telah dilaporkan mampu mengendalikan cendawan patogen antara lain Paenibacillus sp. galur 300 dan Streptomyces sp. galur 358 yang mampu mengendalikan penyakit layu Fusarium pada tanaman ketimun (Singh et al. 1999), Serratia marcescens untuk mengendalikan Sclerotium rolfsii (Fravel et al. 2004), Pseudomonas chlororaphis PA23 yang dikombinasikan dengan Bacillus subtilis BSCBE4 untuk mengendalikan penyakit rebah kecambah pada cabai (Nakkeeran et al. 2006), dan juga Pseudomonas fluorescens yang dikombinasikan dengan $B$. licheniformis dan Chryseobacterium balustinum untuk penyakit yang sama (Domenech et al. 2006).

Sejumlah rizobakteri indigenus lahan Ultisol dari berbagai lokasi di Sulawesi Tenggara dan Sulawesi Selatan dilaporkan memiliki kemampuan menghasilkan enzim kitinase dan menghambat pertumbuhan patogen Fusarium oxysporum secara in vitro, sepuluh di antaranya merupakan bakteri kitinolitik yang kuat (Khaeruni et al. 2010). Penelitian ini bertujuan menyeleksi bakteri tersebut sebagai agens biokontrol penyakit busuk batang pada tanaman kedelai melalui uji daya hambat patogen secara in vitro dan in planta.

\section{BAHAN DAN METODE}

\section{Bakteri Kitinolitik dan $R$. solani}

Sepuluh isolat bakteri kitinolitik dari penelitian Khaeruni et al. (2010) (Kode isolat) digunakan dalam penelitian ini (Tabel 1), sedangkan dua isolat $R$. solani merupakan koleksi Laboratorium Unit HPT-Universitas Haluoleo, berasal dari tanaman kedelai, yaitu isolat RST01 yang diisolasi dari daerah Konawe Selatan, Sulawesi Tenggara dan RJT03 dari daerah Kediri Jawa Timur.

\section{Uji Daya Hambat Bakteri Kitinolitik terhadap $R$. solani}

Isolat bakteri kitinolitik diremajakan pada medium tryptic soy agar (TSA) dengan masa inkubasi dua hari pada suhu ruang. Secara terpisah setiap isolat bakteri kitinolitik uji digoreskan memanjang dengan jarak $3 \mathrm{~cm}$ dari tepi cawan pada medium potato dextrose agar (PDA). Setelah bakteri kitinolitik berumur 24 jam, potongan koloni miselium $R$. solani pada medium PDA dengan diameter $0.5 \mathrm{~cm}$ diinokulasikan pada agar-agar cawan yang telah ditumbuhi bakteri kitinolitik. Koloni $R$. solani diletakkan dengan jarak 3 $\mathrm{cm}$ dari isolat bakteri kitinolitik (Gambar 1). Setiap isolat bakteri kitinolitik uji diulang dua 
Tabel 1 Isolat bakteri kitinolitik yang digunakan dalam penelitian

\begin{tabular}{llcccc}
\hline $\begin{array}{l}\text { Kode } \\
\text { isolat }\end{array}$ & \multicolumn{1}{c}{$\begin{array}{c}\text { Asal isolat } \\
\text { (Kecamatan, Kabupaten, Provinsi) }\end{array}$} & $\begin{array}{c}\mathrm{pH} \\
\text { tanah }\end{array}$ & $\begin{array}{c}\text { Reaksi } \\
\text { Gram }\end{array}$ & $\begin{array}{c}\text { Medium } \\
\text { Kings B }\end{array}$ & $\begin{array}{c}\emptyset \text { zona } \\
\text { kitinolitik } \\
(\mathrm{cm})\end{array}$ \\
\hline ST06d & Konda, Konsel, Sultra & 4.1 & - & - & 2.2 \\
ST17c & Laeya. Konsel, Sultra & 5.4 & - & - & 3.4 \\
ST21b & Laeya, Konsel, Sultra & 5.8 & - & - & 2.6 \\
ST21e & Laeya, Konsel, Sultra & 5.8 & + & - & 4.6 \\
ST26c & Lohia, Muna, Sultra & 5.9 & - & - & 4.6 \\
ST27d & Sawerigading, Muna, Sultra & 4.6 & - & - & 2.8 \\
SS01b & Bajeng, Gowa, Sulsel & 5.7 & - & - & 2.8 \\
SS07c & Bangkalan Tengah, Jeneponto,Sulsel & 5.4 & - & - & 2.2 \\
SS12b & Bangkalan Tengah, Jeneponto,Sulsel & 5.3 & - & + & 2.2 \\
SS17b & Bisappu, Bantaeng, Sulsel & 4.6 & - & - & 2.2 \\
\hline
\end{tabular}

*+, berpendar di bawah lampu UV; -, tidak berpendar

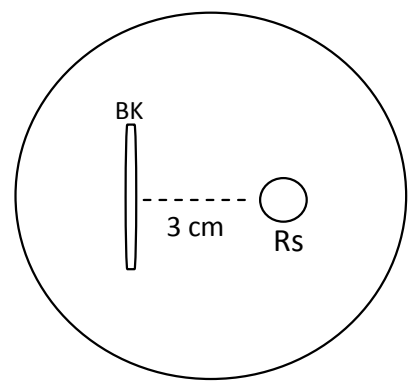

Gambar 1 Uji daya hambat secara in vitro: BK, bakteri kitinolitik uji; Rs, Rhizoctonia solani

kali pada dua isolat $R$. solani, biakan diinkubasikan pada suhu ruang.

Pengamatan dilakukan enam hari setelah isolat dipasangkan. Pertumbuhan $R$. solani diukur jari-jarinya R1, (jari-jari pertumbuhannya ke arah tepi petri) dan R2 (jari-jari pertumbuhannya ke arah bakteri antagonis). Data yang diperoleh digunakan untuk menghitung daya hambat isolat bakteri kitinolitik terhadap $R$. solani menggunakan rumus:

$$
\text { Daya hambat }=\frac{\mathrm{R} 1-\mathrm{R} 2}{\mathrm{R} 1} \times 100 \%
$$

Uji Potensi Bakteri Kitinolitik sebagai Agens Biokontrol untuk $R$. solani pada Tanaman Kedelai secara in Planta di Rumah Kasa

Pengujian disusun berdasarkan pada rancangan acak lengkap dengan enam perlakuan berupa aplikasi lima bakteri (isolat ST21e, isolat SS12b, isolat ST17c, isolat ST27d, dan isolat ST26c) dan kontrol. Enam perlakuan tersebut diaplikasikan pada benih dan tanaman kedelai. Semua perlakuan, kecuali kontrol diinokulasi $R$. solani. Setiap unit perlakuan terdiri atas 10 tanaman dengan 4 kali ulangan sehingga terdapat 240 tanaman.

\section{Medium Tanam}

Medium tanam berupa tanah Ultisol yang telah dikeringanginkan, dihaluskan, dan dicampur dengan pupuk kandang sapi (3:1). Medium ini disterilkan menggunakan autoklaf pada suhu $121{ }^{\circ} \mathrm{C}$ tekanan $1 \mathrm{~atm}$. Medium diisikan ke dalam pot plastik masing-masing sebanyak $2 \mathrm{~kg}_{\text {pot }}{ }^{-1}$.

\section{Penyediaan Inokulum dan Inokulasi Patogen}

Potongan miselium $R$. solani berumur 7 hari pada medium PDA diremajakan dalam $200 \mathrm{~mL}$ potato dextrose broth (PDB) steril dalam tabung erlenmeyer $500 \mathrm{~mL}$ selama 14 hari. Miselium R. solani disaring, dicuci dengan air steril, disaring lagi, dan disuspensikan dengan $500 \mathrm{~mL}$ air steril. Suspensi miselium tersebut dicampurkan dengan pasir steril dengan konsentrasi 1:5 (v/w) dan dijadikan sebagai sumber inokulum. Pasir steril yang mengandung miselium $R$. solani diinokulasikan pada medium tanam sebanyak 
$10 \mathrm{~g} \mathrm{pot}^{-1}$ pada perlakuan yang menggunakan $R$. solani, selanjutnya diinkubasi selama 7 hari dan ditanami benih kedelai varietas Wilis yang telah diberi perlakuan bakteri kitinolitik.

\section{Aplikasi Suspensi Bakteri Kitinolitik}

Inokulasi bakteri kitinolitik dilakukan dengan merendam benih kedelai dalam suspensi bakteri $\left(10^{7} \mathrm{cfu} \mathrm{mL}^{-1}\right)$ selama 6 jam sesuai perlakuan, lalu benih dikeringanginkan dalam laminar air flow, selanjutnya ditanam pada medium dalam pot plastik. Inokulasi bakteri kitinolitik diulang pada saat tanaman berumur 14 hari setelah tanam dengan menyiramkan suspensi bakteri kitinolitik sebanyak $10 \mathrm{~mL}\left(10^{7} \mathrm{cfu} \mathrm{mL}^{-1}\right)$ tanaman $^{-1}$ sesuai perlakuan.

\section{Pengamatan}

Pengamatan setiap minggu dilakukan terhadap kejadian penyakit, tinggi tanaman, dan jumlah daun sejak 2 minggu setelah tanam hingga 6 minggu setelah tanam. Kejadian penyakit ditentukan dengan menghitung jumlah tanaman sakit per jumlah tanaman sampel dalam satuan persen (\%). Data dianalisis dengan analisis sidik ragam, data yang berbeda nyata $(\mathrm{P}<0.05)$ diuji dengan uji jarak berganda Duncan.

\section{HASIL}

\section{Daya Hambat Bakteri Kitinolitik terhadap $R$. solani secara in Vitro}

Hasil pengujian menunjukkan bahwa semua isolat yang diuji memiliki daya hambat terhadap dua isolat $R$. solani uji. Lima isolat memiliki daya hambat tinggi (Tabel 2) kelimanya digunakan untuk uji daya hambat secara in planta.

\section{Potensi Bakteri Kitinolitik sebagai Agens} Biokontrol untuk $R$. solani secara in Planta

Pengamatan kejadian penyakit menunjukkan bahwa perlakuan bakteri kitinolitik mampu menekan kejadian penyakit busuk batang dan terlihat berbeda nyata dibandingkan dengan kontrol. Isolat ST27d
Tabel 2 Daya hambat bakteri kitinolitik terhadap Rhizoctonia solani secara in vitro pada hari ke-6 setelah uji daya hambat

\begin{tabular}{cccc}
\hline Isolat & \multicolumn{2}{c}{$\begin{array}{c}\text { Daya hambat } \\
\text { bakteri kitinoltik } \\
(\%)\end{array}$} & $\begin{array}{c}\text { Rata-rata } \\
\text { daya } \\
\text { hambat } \\
\end{array}$ \\
\cline { 2 - 3 } & K01 & J03 & \\
\hline ST21e & 55.00 & 43.33 & 49.16 \\
SS12b & 53.33 & 38.33 & 45.83 \\
ST17c & 53.33 & 36.67 & 45.00 \\
ST27d & 40.00 & 48.33 & 44.16 \\
ST26c & 48.33 & 36.67 & 42.50 \\
SS01b & 36.67 & 16.67 & 26.67 \\
SS07c & 36.67 & 16.67 & 26.67 \\
SS12b & 36.67 & 6.67 & 21.67 \\
SS17b & 36.67 & 6.67 & 21.67 \\
\hline
\end{tabular}

dan ST17c tidak menunjukkan terjadinya penyakit busuk batang sampai akhir pengamatan, sedangkan pada kontrol kejadian penyakit mencapai $67.5 \%$ (Tabel 3).

Hasil pengamatan tinggi kedelai menunjukkan bahwa perlakuan ST27d selalu memperlihatkan tinggi tanaman terbaik dan berbeda nyata dibandingkan dengan perlakuan lain pada setiap pengamatan. Pada pengamatan minggu ke-6 perlakuan isolat ST27d memiliki tinggi terbaik, disusul oleh perlakuan ST17c (Tabel 4).

Isolat bakteri kitinolitik yang berbeda juga berpengaruh nyata terhadap jumlah daun kedelai yang terbentuk. Dua perlakuan terbanyak daun trifoliatnya ialah pada isolat ST27d dan isolat ST17c (Tabel 5), masingmasing dengan jumlah daun sebanyak 32 helai dan 24 helai.

\section{PEMBAHASAN}

Bakteri kitinolitik adalah bakteri yang mampu mendegradasi senyawa kitin. Bakteri kitinolitik yang digunakan dalam penelitian ini adalah golongan bakteri rizosfer yang diisolasi dari perakaran tanaman di tanah Ultisol (Khaeruni et al. 2010). Aktivitas kitinolitik ditandai dengan adanya 
Tabel 3 Pengaruh aplikasi bakteri kitinolitik terhadap kejadian penyakit busuk batang pada kedelai yang diinokulasi Rhizoctonia solani

\begin{tabular}{lcrrrr}
\hline \multirow{2}{*}{$\begin{array}{c}\text { Perlakuan } \\
\text { isolat }\end{array}$} & \multicolumn{5}{c}{ Kejadian penyakit (\%) pada pengamatan } \\
\cline { 2 - 6 } & \multicolumn{1}{c}{ II } & \multicolumn{1}{c}{ III } & \multicolumn{1}{c}{ IV } & \multicolumn{1}{c}{ V } & \multicolumn{1}{c}{ VI } \\
\hline ST21e & 0.00 & $2.50 \mathrm{a}$ & $10.00 \mathrm{c}$ & $15.00 \mathrm{c}$ & $15.00 \mathrm{c}$ \\
SS12b & 0.00 & $0.00 \mathrm{a}$ & $5.00 \mathrm{~b}$ & $7.50 \mathrm{~b}$ & $7.50 \mathrm{~b}$ \\
ST17c & 0.00 & $0.00 \mathrm{a}$ & $0.00 \mathrm{a}$ & $0.00 \mathrm{a}$ & $0.00 \mathrm{a}$ \\
ST27d & 0.00 & $0.00 \mathrm{a}$ & $0.00 \mathrm{a}$ & $0.00 \mathrm{a}$ & $0.00 \mathrm{a}$ \\
ST26c & 0.00 & $10.00 \mathrm{~b}$ & $17.50 \mathrm{c}$ & $30.00 \mathrm{~d}$ & $30.00 \mathrm{~d}$ \\
Kontrol & 0.00 & $20.00 \mathrm{c}$ & $47.50 \mathrm{~d}$ & $62.50 \mathrm{e}$ & $67.50 \mathrm{e}$ \\
\hline
\end{tabular}

${ }^{\star}$ Angka yang diikuti oleh huruf yang sama pada kolom yang sama tidak berbeda nyata pada taraf kepercayaan $95 \%$

Tabel 4 Pengaruh aplikasi bakteri kitinolitik terhadap tinggi tanaman kedelai yang diinokulasi Rhizoctonia solani

\begin{tabular}{lccccr}
\hline \multirow{2}{*}{$\begin{array}{c}\text { Perlakuan } \\
\text { isolat }\end{array}$} & \multicolumn{5}{c}{ Rata-rata tinggi tanaman $(\mathrm{cm})$ pada minggu ... setelah tanam } \\
\cline { 2 - 6 } & II & III & IV & V & \multicolumn{1}{c}{ VI } \\
\hline ST21e & $10.21 \mathrm{~b}$ & $15.01 \mathrm{bc}$ & $18.16 \mathrm{~b}$ & $31.31 \mathrm{~b}$ & $15.00 \mathrm{c}$ \\
SS12b & $10.71 \mathrm{bc}$ & $16.63 \mathrm{~cd}$ & $20.77 \mathrm{bc}$ & $37.69 \mathrm{bc}$ & $7.50 \mathrm{~b}$ \\
ST17c & $12.22 \mathrm{c}$ & $19.42 \mathrm{~d}$ & $24.81 \mathrm{c}$ & $48.99 \mathrm{c}$ & $0.00 \mathrm{a}$ \\
ST27d & $15.78 \mathrm{~d}$ & $26.54 \mathrm{e}$ & $38.73 \mathrm{~d}$ & $75.28 \mathrm{~d}$ & $0.00 \mathrm{a}$ \\
ST26c & $9.51 \mathrm{~b}$ & $13.35 \mathrm{~b}$ & $16.50 \mathrm{ab}$ & $29.44 \mathrm{a}$ & $30.00 \mathrm{~d}$ \\
Kontrol & $6.77 \mathrm{a}$ & $9.03 \mathrm{a}$ & $12.13 \mathrm{a}$ & $17.45 \mathrm{a}$ & $67.50 \mathrm{e}$ \\
\hline
\end{tabular}

${ }^{*}$ Angka yang diikuti oleh huruf yang sama pada kolom yang sama tidak berbeda nyata pada taraf kepercayaan $95 \%$

Tabel 5 Pengaruh aplikasi bakteri kitinolitik terhadap jumlah daun kedelai yang diinokulasi Rhizoctonia solani

\begin{tabular}{lccccc}
\hline \multirow{2}{*}{$\begin{array}{c}\text { Perlakuan } \\
\text { isolat }\end{array}$} & \multicolumn{5}{c}{ Rata-rata jumlah daun (helai) } \\
\cline { 2 - 6 } & II & III & IV & V minggu ... setelah tanam ${ }^{\star}$ & VI \\
\hline ST21e & $3 \mathrm{a}$ & $7 \mathrm{bc}$ & $9 \mathrm{~b}$ & $14 \mathrm{bc}$ & $21 \mathrm{bc}$ \\
SS12b & $3 \mathrm{a}$ & $7 \mathrm{~cd}$ & $9 \mathrm{bc}$ & $15 \mathrm{c}$ & $21 \mathrm{bc}$ \\
ST17c & $3 \mathrm{a}$ & $8 \mathrm{~d}$ & $11 \mathrm{~cd}$ & $17 \mathrm{~d}$ & $24 \mathrm{c}$ \\
ST27d & $6 \mathrm{~b}$ & $10 \mathrm{e}$ & $13 \mathrm{~d}$ & $21 \mathrm{e}$ & $32 \mathrm{~d}$ \\
ST26c & $2 \mathrm{a}$ & $5 \mathrm{~b}$ & $8 \mathrm{~b}$ & $12 \mathrm{~b}$ & $18 \mathrm{~b}$ \\
Kontrol & $2 \mathrm{a}$ & $3 \mathrm{a}$ & $5 \mathrm{a}$ & $9 \mathrm{a}$ & $13 \mathrm{a}$ \\
\hline
\end{tabular}

${ }^{\star}$ Angka yang diikuti oleh huruf yang sama pada kolom yang sama tidak berbeda nyata pada taraf kepercayaan 95\%

pembentukan zona bening ketika ditumbuhkan pada medium yang mengandung kitin. Semua isolat yang digunakan menghasilkan zona bening di sekitar lubang suspensi dengan diameter yang bervariasi dari $2.2 \mathrm{~cm}$ sampai $4.6 \mathrm{~cm}$ (Khaeruni et al. 2010)
Cendawan $R$. solani memiliki struktur dinding sel yang mengandung kitin. Pada pengamatan daya hambat pertumbuhan $R$. solani secara in vitro terlihat bahwa bakteri kitinolitik memiliki kualitas degradasi kitin yang kuat terhadap perkembangan $R$. solani secara in vitro, misalnya isolat ST21e memiliki kemampuan 
degredasinya kitin ditunjukkan dari diameter zona daya hambat yang mencapai $4.6 \mathrm{~cm}$ terhadap dua isolat $R$. solani (Tabel 2).

Satu hal yang menarik pada uji daya hambat in vitro ialah isolat ST27d, walaupun zona kitinolitiknya hanya $2.8 \mathrm{~cm}$, tetapi memiliki daya hambat terhadap pertumbuhan dua isolat $R$. solani yang cukup kuat, yaitu 40.00 dan $48.33 \%$ (Tabel 2). Adanya fenomena tersebut mengindikasikan bahwa enzim kitinase bukan satu-satunya faktor penghambat pertumbuhan cendawan patogen. Fatima et al. (2008) menjelaskan bahwa rizobakteri memproduksi senyawa siderofor dan nitrogen sianida, enzim kitinase, protease, dan beberapa enzim lain yang beracun bagi cendawan patogen sehingga dapat menghambat pertumbuhan dan perkembangan patogen.

Bakteri uji yang memiliki rata-rata daya hambat kuat terhadap dua isolat $R$. solani secara in vitro $(>30 \%)$ berturut-turut ialah ST21e, SS12b, ST17c, ST27d, dan ST26c. Isolat bakteri ini diuji potensinya sebagai agens biokontrol $R$. solani secara in planta berdasarkan pada kemampuannya untuk menekan kejadian penyakit busuk batang.

Kejadian penyakit busuk batang pada tanaman kedelai dapat dilihat dari luar tanaman dengan mengamati gejala eksternal yang ditampakkan. Tanaman yang terserang patogen akan menujukkan gejala layu yang diawali dengan menguningnya daun tanaman. Gejala pada batang ditandai timbulnya bercakbercak cokelat, yang cepat melebar sehingga batang tanaman menjadi busuk mengering dan berwarna cokelat. Menguningnya daun dan timbulnya bercak cokelat pada tanaman kedelai disebabkan oleh adanya serangan $R$. solani pada jaringan pembuluh tanaman. Keberadaan patogen tersebut menyebabkan tanaman tidak mendapat suplai air, mineral, dan unsur hara dari dalam tanah.

Hasil penelitian ini memperlihatkan bahwa tanaman kedelai yang mendapat perlakuan dengan aplikasi bakteri kitinolitik, kejadian penyakitnya lebih rendah dibandingkan dengan perlakuan kontrol. Bahkan, ada tanaman yang diaplikasi dengan isolat bakteri ST27d dan isolat ST17c sama sekali tidak menunjukkan kejadian penyakit sampai minggu keenam atau pada pengamatan terakhir. Hasil ini menunjukkan bahwa kedua isolat tersebut memiliki potensi penghambatan terhadap cendawan patogen lebih besar daripada yang dilaporkan sebelumnya (Suryanto 2010). Rendahnya kejadian penyakit pada perlakuan yang diaplikasi dengan bakteri kitinolitik ialah karena isolat tersebut menghasilkan enzim kitinase yang mampu mendegradasi kitin yang merupakan salah satu komponen penyusun dinding sel cendawan $R$. solani.

Aplikasi bakteri kitinolitik juga berpengaruh nyata terhadap pertumbuhan tanaman kedelai, tinggi tanaman, dan jumlah daun karena bakteri kitinolitik ini adalah bakteri rizosfer yang diisolasi dari sekitar perakaran tanaman yang juga memacu pertumbuhan tanaman (Khaeruni et al. 2010). Ramamoorthy et al. (2002); Fatima et al. (2009), dan Mia et al. (2010) juga melaporkan beberapa rizobakteri memiliki kemampuan sebagai pemacu pertumbuhan tanaman dan sekaligus sebagai agens biokontrol.

Isolat bakteri ST27d menunjukkan pertumbuhan terbaik dengan rata-rata tinggi tanaman $91.78 \mathrm{~cm}$ dan jumlah daun terbanyak 32 helai pada pengamatan minggu keenam (Tabel 4). Pertumbuhan yang lebih baik yang terjadi pada tanaman yang diaplikasi bakteri kitinolitik ini disebabkan karena adanya aktivitas bakteri kitinolitik yang juga berperan sebagai rizobakteri yang menguntungkan tanaman untuk menyediakan dan memobilisasi penyerapan unsur hara dari dalam tanah, melarutkan fosfor, dan menghasilkan hormon tumbuh (Thakuria et al. 2004). Isolat yang digunakan dalam penelitian ini adalah isolat yang memiliki kemampuan menghasilkan IAA, melarutkan fosfat, dan menfiksasi nitrogen dari udara bebas yang kemampuannya bervariasi (Khaeruni et al. 2010). Bustaman (2006) mengemukakan bahwa perbaikan pertumbuhan tanaman dapat disebabkan oleh kemampuan mikroorganisme 
untuk menggunakan nutrisi dari bahan organik dan tanah sehingga lebih tersedia dan mudah diambil oleh tanaman.

Tanaman yang diaplikasi isolat ST27d dan ST17c selain tidak memperlihatkan kejadian penyakit busuk batang juga memiliki pertumbuhan vegetatif yang lebih baik. Oleh karena itu, keduanya berpotensi dikembangkan sebagai agens biokontrol penyakit busuk batang dan pemacu pertumbuhan tanaman kedelai.

\section{UCAPAN TERIMA KASIH}

Penelitian ini merupakan bagian dari Penelitian Riset Unggulan Nasional yang dibiayai melalui DIPA Universitas Haluoleo, Kendari dengan Nomor Kontrak: 053a/ H29.10/PG/2009, tahun 2009

\section{DAFTAR PUSTAKA}

Bustaman H. 2006. Seleksi mikroba rizobakteri antagonis terhadap bakteri Ralstonia solanacearum penyebab penyakit bakteri pada tanaman jahe di lahan tertindas [skripsi]. Bengkulu (ID): Universitas Bengkulu.

Domenech J, Reddy MS, Kloepper JW, Ramos B, Manero FJG. 2006. Combined application of the biological product LS213 with Bacillus, Pseudomonas or Chryseobacterium for growth promotion and biological control of soilborne diseases in pepper and tomato. Bio Control. 51(2):245-258. doi:10.1007/s10520-0052940-2.

Fatima Z, Saleemin M, Zia M, Sultan T, Asham M, Rehman RU, Chaudhary MF. 2009. Antifungal activity of plant growth-promoting rhizobacteria isolates againt Rhizoctonia solani in wheat. Afr J Biotech. 8(2):219-225.

Fravel LJ, Wanten P, Blok W. 2004. Biological soil disinfestation: a safe and effective approach for controlling soilborne pests and diseases. Agroindustria. 3(3):289-291.

Khaeruni A, Sutariati GAK, Wahyuni S.
2010. Karakterisasi dan uji aktivitas bakteri rizosfer lahan ultisol sebagai pemacu pertumbuhan dan agensia hayati cendawan patogen tular tanah secara in vitro. J Hama Penyakit Tumbuhan Tropika. 10(2):123-130.

Mia MAB, Shamsuddin ZH, Mahmood M. 2010. Use of plant growth promoting bacteria in banana: a new insight for sustainable banana production. Int J Agric Biol. 12:459-467. doi: 09-279/SBC/2010/ 12-3-459-467.

Nakkeeran S, Kavitha K, Chandrasekar G, Renukadevi P, Fernando WGD. 2006. Induction of plant defense compounds by Pseudomonas chlororaphis PA23 and Bacillus subtilis BSCBE4 in controlling damping-off of hot pepper caused by Pythium aphanidermatum. Biocont Sci Tech. 16(4):403-416. doi: 10.1080/09583150500532196.

Ramamoorthy V, Raguchander T, Samiyappan R. 2002. Induction of defense-related proteins in tomato roots treated with Pseudomonas fluorescens dan Fusarium oxysporum f. sp. lycopersici. Plant Soil. 239:55-68.

Singh PP, Shin CS, Park CS, Chung YR. 1999. Biological control of fusarium wilt of cucumber by chitinolitic bacteria. Phytopathology. 89(1):92-99. doi:10.1094/ Phyto.1999. 89.1.92.

Suryanto D, Patonah S, Munir E. 2010. Control of fusarium wilt of chili with chitinolytic bacteria. Hayati J Biosci. 17(1):5-8. doi:10.4308/hjb.17.1.5.

Thakuria D, Talukdar NC, Goswami C, Hazarika S, Boro RC, Khan MR. 2004. Characterization and screening of bacteria from rhizosphere of rice grown in acidic soils of Assam. Curr Sci. 86:978-985.

Wei G, Klopper JW, Tuzun S. 1990. Induction of systemic resistance of cucumber to Colletotrichum orbiculare by selected strain of plant growth promoting rhizobacteria. Phytopathology. 81(12):15081512.doi: 10.1094/Phyto-81-1508. 